\title{
CD47 deficiency protects cardiomyocytes against hypoxia/reoxygenation injury by rescuing autophagic clearance
}

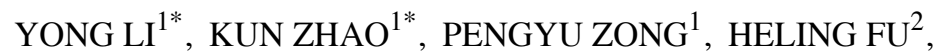 \\ YUAN ZHENG ${ }^{2}$, DAN BAO $^{2}$, YUAN YIN $^{2}$, QIN CHEN $^{2}$, LU LU $^{2}$, \\ YOUJIN DAI ${ }^{2}$, DAORONG HOU ${ }^{2}$ and XIANGQING KONG ${ }^{1}$ \\ ${ }^{1}$ Department of Cardiology, The First Affiliated Hospital of Nanjing Medical University; \\ ${ }^{2}$ Key Laboratory of The Model Animal Research, Animal Core Facility of Nanjing Medical University, \\ Nanjing Medical University, Nanjing, Jiangsu 210029, P.R. China
}

Received October 19, 2018; Accepted April 4, 2019

DOI: $10.3892 / \mathrm{mmr} .2019 .10199$

\begin{abstract}
To assess the effect of cluster of differentiation (CD47) downregulation on autophagy in hypoxia/reoxygenation (H/R)-treated $\mathrm{H} 9 \mathrm{c} 2$ cardiomyocytes. $\mathrm{H} 9 \mathrm{c} 2$ cells were maintained in normoxic conditions $(95 \%$ air, $5 \% \mathrm{CO}_{2}, 37^{\circ} \mathrm{C}$ ) without $\mathrm{CD} 47$ antibodies, Si-CD47 or chloroquine $(\mathrm{CQ})$ treatment; $\mathrm{H} 9 \mathrm{c} 2$ cells in the $\mathrm{H} / \mathrm{R}$ group were subjected to $24 \mathrm{~h}$ of hypoxia $\left(1 \% \mathrm{O}_{2}, 94 \% \mathrm{~N}_{2}, 5 \% \mathrm{CO}_{2}, 37^{\circ} \mathrm{C}\right)$ followed by $12 \mathrm{~h}$ of reoxygenation $\left(95 \%\right.$ air, $\left.5 \% \mathrm{CO}_{2}, 37^{\circ} \mathrm{C}\right)$. All assays were controlled, triplicated and repeated on three separately initiated cultures. The biochemical parameters in the medium supernatant were measured to evaluate the oxidative stress in cardiomyocytes. The Annexin V-fluorescein isothiocyanate assay was used to detect the apoptotic rate in the H9c2 cells. Transmission electron microscope, immunofluorescent staining and western blot analysis were performed to detect the effect of the CD47 antibody on autophagic flux in H/R-treated H9c2 cardiomyocytes. The cardiomyocytic oxidative stress and apoptotic rate decreased and autophagic clearance increased after CD47 downregulation. H/R triggered cell autophagy, autophagosome accumulation and
\end{abstract}

Correspondence to: Dr Daorong Hou, Key Laboratory of The Model Animal Research, Animal Core Facility of Nanjing Medical University, Nanjing Medical University, 101 Longmian Avenue, Nanjing, Jiangsu 210029, P.R. China

E-mail: houdaorong@njmu.edu.cn

Professor Xiangqing Kong, Department of Cardiology, The First Affiliated Hospital of Nanjing Medical University, 300 Guangzhou Road, Nanjing, Jiangsu 210029, P.R. China

E-mail: xiangqing_kong@sina.com

${ }^{*}$ Contributed equally

Key words: autophagy, CD47 antibody, CD47 knock-down, hypoxia/ reoxygenation apoptosis in H9c2 cell lines. However, these effects can be attenuated by CD47 downregulation. This study demonstrates its clinical implications in ischemia/reperfusion injury treatment.

\section{Introduction}

Ischemic heart disease is a leading cause of mortality in a number of countries, especially the United States $(1,2)$. Despite the advances in therapeutic strategy over the past decade, such as percutaneous coronary intervention, antiplatelet and antithrombotic therapies and angioplasty, ischemic heart disease remains prevalent and a major culprit for heart failure $(3,4)$.

One therapeutic strategy for this disease is controlling ischemia/reperfusion ( $\mathrm{I} / \mathrm{R})$ injury $(5,6)$, that can activate autophagy and consequent cell apoptosis (7). When the ischemic myocardium is re-perfused with oxygen and substrate-rich blood, I/R injury develops to further damage the heart (4). Therefore, an increasing number of studies have been carried out to investigate the myocytic autophagy and apoptosis induced by I/R injury (8-10).

CD47 signal controls second messengers, such as calcium, cAMP and cGMP. In vascular cells, CD47 inhibits the production and effector pathways of nitric oxide (NO). Therefore, CD47 signaling can regulate blood flow, platelet homeostasis and angiogenesis $(11,12)$. Studies have demonstrated that reducing or blocking CD47 can profoundly protect cells and tissues from apoptosis induced by I/R injury (11-19) or radiation injury through activating autophagic flux (20-22). But so far, the effect of CD47 downregulation on myocytic autophagy induced by $\mathrm{I} / \mathrm{R}$ injury remains unclear.

A hypoxia/reoxygenation $(\mathrm{H} / \mathrm{R})$ in vitro model is appropriate for exploring the molecular mechanisms and functions of autophagy during myocardial ischemia/reperfusion (I/R) (23). In this study, using the H9c2 cell line to model I/R injury induced cardiomyocyte apoptosis, the effect of CD47 on cellular I/R injury and autophagy was investigated. 


\section{Materials and methods}

H9c2 cell culture. The H9c2 cells (ventricular myocardiocyte, rat in origin; Cell Bank of the Chinese Academy of Sciences, Shanghai, China) were seeded in 6 -well plates $\left(2 \times 10^{4}\right.$ cells $\left./ \mathrm{cm}^{2}\right)$ and cultured in Dulbecco's modified Eagle's medium (Sigma-Aldrich; Merck KGaA, Darmstadt, Germany) containing $10 \%$ (v/v) fetal bovine serum (Gibco; Thermo Fisher Scientific, Inc., Waltham, MA, USA) and $100 \mathrm{mmol} / 1$ penicillin-streptomycin in a humidified atmosphere $\left(95 \%\right.$ air and $\left.5 \% \mathrm{CO}_{2}, 37^{\circ} \mathrm{C}\right)$. The medium was replenished every two days.

$H / R$ in $H 9 c 2$. Cardiomyocyte hypoxia was induced by exposing the cells to $1 \% \mathrm{O}_{2}, 94 \% \mathrm{~N}_{2}$ and $5 \% \mathrm{CO}_{2}$ for $24 \mathrm{~h}$ in a modular incubator (Model 3131; Forma Scientific; Thermo Fisher Scientific, Inc.). Then the cells were reoxygenated (95\% air, $5 \% \mathrm{CO}_{2}, 37^{\circ} \mathrm{C}$ ) for $12 \mathrm{~h}(24)$. Cells under normoxia were used as a control throughout the experiments. All experiments were repeated three times.

Transfection. H9c2 cells were digested to form a single-cell suspension and plated in 6-well plates until the cells entered the logarithmic growth phase. When the cell density reached $\sim 80 \%, 20 \mathrm{nM}$ short interfering $(\mathrm{Si})$ - $\mathrm{CD} 47$ or a scrambled Si-RNA (Si-NC) was transfected into the cells using Lipofectamine 2000 (Thermo Fisher Scientific, Inc.) according to the manufacturer's protocols. The sequences of siRNAs are: Si-CD47, 5'-AGAUUUGACUUUACUAAG CAG-3' and Si-NC, 5'-UUCUCCGAACGUGUCACGUTT-3'. After $24 \mathrm{~h}$ of transfection, the mRNA expression of CD47 was determined by reverse transcription-quantitative polymerase chain reaction (RT-qPCR).

Experiment design. A total of two experiments were performed. In experiment $1, \mathrm{H} 9 \mathrm{c} 2$ cells were assigned to 5 groups. i) Control group: H9c2 cells were maintained under normoxic conditions without the CD47 antibody (cat. no. sc-53050; Santa Cruz Biotechnology, Inc., Dallas, TX, USA) or CQ treatment; ii) H/R group: H9c2 cells were subjected to $24 \mathrm{~h}$ of hypoxia followed by $12 \mathrm{~h}$ of reoxygenation (24); iii) CD47 group: H9c2 cells were treated with the CD47 antibody ( $7 \mu \mathrm{g} / \mathrm{ml}$ for $2 \mathrm{~h})$ and incubated under normoxic conditions (25); iv) $\mathrm{H} / \mathrm{R}+\mathrm{CD} 47$ group: $\mathrm{H} 9 \mathrm{c} 2$ cells treated with the CD47 antibody were subjected to $24 \mathrm{~h}$ of hypoxia followed by $12 \mathrm{~h}$ of reoxygenation; v) $\mathrm{H} / \mathrm{R}+\mathrm{CD} 47+\mathrm{CQ}$ group: $\mathrm{H} 9 \mathrm{c} 2$ cells treated with CD47 antibody $(7 \mu \mathrm{g} / \mathrm{ml}$ for $2 \mathrm{~h})$ and CQ (10 mmol/l for $1 \mathrm{~h}$; C6628; Sigma-Aldrich; Merck KGaA) were subjected to $24 \mathrm{~h}$ of hypoxia followed by $12 \mathrm{~h}$ of reoxygenation. CQ was used to inhibit lysosomal acidification and autophagosome-lysosome fusion (26). H9c2 cells were treated with CD47 and CQ for the indicated times as described previously $(25,26)$. In experiment 2, $\mathrm{H} 9 \mathrm{c} 2$ cells were assigned to 3 groups: i) $\mathrm{Si}-\mathrm{NC}+\mathrm{H} / \mathrm{R}$ : $\mathrm{H} 9 \mathrm{c} 2$ cells treated with $\mathrm{Si}-\mathrm{NC}$ were subjected to $24 \mathrm{~h}$ of hypoxia followed by $12 \mathrm{~h}$ of reoxygenation; ii) $\mathrm{Si}-\mathrm{CD} 47$ : H9c2 cells treated with SiCD47; iii) Si-CD47+H/R: H9c2 cells treated with $\mathrm{Si}-\mathrm{CD} 47$ were subjected to $24 \mathrm{~h}$ of hypoxia followed by $12 \mathrm{~h}$ of reoxygenation. All experiments were repeated three times.
Determination of cell injury. Using commercially available kits for malondialdehyde (MDA; cat. no. A003-1), lactate dehydrogenase (LDH; cat. no. A020-2), creatinine kinase-muscle/brain (CK-MB; cat. no. H197) and superoxide dismutase (SOD; cat. no. A001-1; Nanjing Jiancheng Bioengineering Institute, Nanjing, China), the biochemical parameters of the medium supernatant and $\mathrm{H} 9 \mathrm{c} 2$ cells were measured.

Reactive oxygen species (ROS) staining. To evaluate cell production of ROS, the slides of cells were incubated with $10 \mu \mathrm{mol} / 1$ dihydroethidium (DHE; D-23107; Invitrogen, Thermo Fisher Scientific, Inc.) in PBS in the dark for exactly $30 \mathrm{~min}$ at room temperature. Then, the sections were rinsed twice with cold PBS and imaged at 490-560 nm using an Olympus microscope (1-71, Olympus Corporation) immediately.

Determination of cellular apoptosis. To detect the apoptosis rate of the $\mathrm{H} 9 \mathrm{C} 2$ cells, we used an Annexin V-fluorescein isothiocyanate (FITC) Assay kit (cat. no. 556547; BD Biosciences; Becton, Dickinson and Company, Franklin Lakes, NJ, USA). Briefly, the granulosa cells were washed twice with cold PBS which was removed afterwards from the cell pellet. The cells were resuspended in $500 \mu 1$ of binding buffer. Then $5 \mu \mathrm{l}$ of Annexin V-FITC and $5 \mu \mathrm{l}$ of PI staining solution was added. The cells were vortexed, incubated for $15 \mathrm{~min}$ in the dark and detected by flow cytometer (BD FACSCalibur; BD Biosciences; Becton, Dickinson and Company). The mean fluorescent intensity of the annexin V/PI double staining in the myocytes was analyzed using FlowJo software version 10.4.2 (FlowJo LLC). The proportion of apoptotic cells (mortality) was defined as the percentage of Annexin $\mathrm{V}^{+}$-FITC ${ }^{+}$cells ( $\mathrm{n}=9$ per group).

Electron microscopy. For transmission electron microscope (TEM) examination, cells were digested and centrifuged $\left(800 \mathrm{xg}\right.$ for $5 \mathrm{~min}$ at $\left.25^{\circ} \mathrm{C}\right)$ to form cell pellets, and fixed in $2.5 \%$ glutaraldehyde for $48 \mathrm{~h}$ at $4^{\circ} \mathrm{C}$, postfixed in $0.5 \%$ osmium tetroxide, dehydrated and embedded in epoxy resin. Ultrathin sections (90 $\mathrm{nm}$ thick) were made and examined using transmission electron microscope (Tecnai G2 Spirit Bio TWIN; FEI Ltd.) at accelerating voltage $80 \mathrm{kV}$ and $\times 10,000$ magnification. Electron micrographs (five fields of view per cell) were randomly examined (five cells at four corners and in the middle were selected) for each experiment ( $n=9$ per group).

Immunofluorescent staining. For immunofluorescent staining, H9c2 were rinsed in Dulbecco's PBS (DPBS) for $5 \mathrm{~min}$ at room temperature, then fixed in $4 \%$ paraformaldehyde in DPBS at $25^{\circ} \mathrm{C}$ for $10 \mathrm{~min}$. After being washed with DPBS, the cells were permeabilized in $1 \%$ Triton X-100 for $1 \mathrm{~h}$ and eventually blocked in 10\% goat serum (blocking solution, cat. no. 16210072; Gibco; Thermo Fisher Scientific, Inc.) for $1 \mathrm{~h}$ at room temperature to inhibit nonspecific binding. Primary antibodies included CD47 (cat. no. sc-53050; Santa Cruz Biotechnology, Inc.), Beclin-1 (cat. no. sc-48341; Santa Cruz Biotechnology, Inc.), SQSTM1/p62 (p62; cat. no. 23214; Cell Signal Technology, Inc., USA) and Vimentin (cat. no. 5741; Cell Signal Technology, Inc.). All the cells were treated with primary antibodies in the 
blocking solution for $24 \mathrm{~h}$ at $4^{\circ} \mathrm{C}$. Subsequently, the cells were rinsed in $1 \mathrm{X}$ DPBS and incubated with secondary antibodies in the blocking solution for $1 \mathrm{~h}$ at $4^{\circ} \mathrm{C}$. Alexa Fluor 546 goat anti-mouse $\operatorname{lgG}(\mathrm{H}+\mathrm{L})$ (1:200; cat. no. A11030; Invitrogen; Thermo Fisher Scientific, Inc.) and donkey anti-rabbit-CY3 (1:200; cat. no. A21206; Molecular Probes; Thermo Fisher Scientific, Inc.) were used as secondary antibodies. The cells were then washed and stained with DAPI (Fluoroshield with DAPI, F6057; Gibco; Thermo Fisher Scientific, Inc.). The stained cells were examined using confocal images system (710; Zeiss AG, Oberkochen Germany). All the sections were incubated with the antibodies at the same concentration and under the same condition. The tissue section images were captures at 490-560 nm with an Olympus microscope (1-71; Olympus Corporation) and semi-quantified with Image Pro Plus 6.0 software (Media Cybernetics, Inc.). The integrated optical density (IOD) was collected for each photograph. A total of five fields in each slice (five slides per animal) were randomly selected for blinded measurements ( $n=6$ per group). The images were quantified by the immunoreactive area (IA) in $\mu \mathrm{m}^{2}$ and the IOD. The staining intensity (SI) for each image was calculated as $\mathrm{SI}=\mathrm{IOD} / \mathrm{IA}$ and the mean with standard deviation was obtained for each series.

$R T-q P C R$. RT-qPCR was performed according to previously described methods (27). Following $48 \mathrm{~h}$ of transfection with Si-CD47 or SiNC, total RNA from H9C2 cells was extracted using TRIzol reagent (B5704-1; Takara Biotechnology, Co., Ltd., Dalian, China). Then, $1 \mu \mathrm{g}$ of total RNA was reverse transcribed to cDNA at $37^{\circ} \mathrm{C}$ for $15 \mathrm{~min}$ and $85^{\circ} \mathrm{C}$ for $5 \mathrm{sec}$ using PrimeScript ${ }^{\mathrm{TM}}$ RT reagent kit (cat. no. RR037A; Takara Biotechnology, Co., Ltd.). Subsequently, PCR was performed using a Light Cycler PCR QC kit (Roche Applied Science) and 7300 Real-Time PCR System (LC96; Roche Applied Science). In the $25 \mu \mathrm{l}$ reaction system, $300 \mathrm{nmol} / 1$ primers were added. The thermo cycling conditions were: $2 \mathrm{~min}$ at $50^{\circ} \mathrm{C}$ and $10 \mathrm{~min}$ at $95^{\circ} \mathrm{C}$, followed by 40 cycles of $15 \mathrm{sec}$ at $95^{\circ} \mathrm{C}$ and $1 \mathrm{~min}$ at $60^{\circ} \mathrm{C}$. The primers were as follows: CD47 (NM_019195.2) forward: 5'-AGAGAATCATTCTGCTGCTGGTTGC-3', reverse: 5'-TGGTGAAAGAGGTCATTCCAAAAGC-3'; GAPDH (NM_017008.4), forward: 5'-CTGGAGAAACCT GCCAAGTATG-3', reverse: 5'-GGTGGAAGAATGGGA GTTGCT-3'. The housekeeping gene GAPDH was used as an internal reference. GraphPad Prism 5 software (GraphPad Software, Inc.) was used for chart production.

Western blot analysis. The cells were harvested in RIPA lysis buffer (Bioteke Corporation, Beijing, China) containing $1 \mathrm{mM}$ phenylmethylsulfonyl fluoride. Protein concentration was measured using the Bio-Rad method. Samples $(20 \mathrm{mg}$ protein) were separated by $10 \%$ SDS-PAGE and transferred to a nitrocellulose membrane. The membrane was blocked with $5 \%$ non-fat milk in TBST buffer $(100 \mathrm{mM} \mathrm{NaCl}, 10 \mathrm{mM}$ Tris- $\mathrm{HCl}, \mathrm{pH} 7.4,0.1 \%$ Tween-20) at $25^{\circ} \mathrm{C}$ for $1 \mathrm{~h}$, incubated with the primary antibodies against LC3 (1:1,000, cat. no. 4108; Cell Signal Technology, Inc.), Beclin-1 (1:1,000, cat. no. sc-48341; Santa Cruz Biotechnology, Inc.), p62 (1:1,000, 23214; Cell Signal Technology, Inc.), LAMP2 (1:1,000, cat. no. sc-71492; Santa Cruz Biotechnology, Inc.), cleaved caspase-3 (1:1,000, cat. no. 9664; Cell Signal Technology, Inc.), cleaved caspase-9 (1:1,000, cat. no. 7237; Cell Signal Technology, Inc.) and GAPDH (1:1,000, cat. no. sc-166574, Santa Cruz Biotechnology, Inc.) at $4{ }^{\circ} \mathrm{C}$ overnight, and re-incubated with goat anti-rabbit IgG HRP-conjugated secondary antibodies (1:5,000, cat. no. sc-2004; Santa Cruz Biotechnology, Inc.) or goat anti-mouse IgG HRP-conjugated secondary antibodies (1:5,000, cat. no. sc-2005; Santa Cruz Biotechnology, Inc.). Then, the membranes were washed three times in TBST. The blots were imaged using the ChemiDoc XRS+ Molecular Imager (Bio-Rad Laboratories, Inc.) with the Pierce ECL Western Blotting Substrate (cat. no. 32209; Thermo Fisher Scientific, Inc.) and analyzed using image analysis software (ImageJ 1.42; National Institutes of Health, Bethesda, MD, USA). The housekeeping protein GAPDH was used as the internal control. The western blotting quantification was corrected to GAPDH expression prior to normalization.

Statistical analysis. All data were presented as the mean \pm standard error and analyzed using SPSS 13.0 (SPSS, Inc.). One-way analysis of variance was used to determine statistical significance. Bonferroni post hoc test was introduced as needed. $\mathrm{P}<0.05$ was considered to indicate a statistically significant difference. All experiments were repeated three times.

\section{Results}

CD47 protects cardiomyocytes against $H / R$-induced oxidative stress and apoptosis in cardiomyocytes. The effects of the CD47 antibody on cardiomyocyte function and oxidative stress levels in $\mathrm{H} 9 \mathrm{c} 2$ cells are presented in Fig. 1A-D. There was no significant difference in $\mathrm{LDH}$, CK-MB, MDA and SOD levels between the control and CD47 groups. Compared with the control group, H/R treatment significantly increased LDH, CK-MB and MDA levels and significantly decreased SOD activity in the culture media in the $H / R$ group $(\mathrm{P}<0.01)$. Compared with the H/R group, CD47 antibody treatment significantly decreased LDH, CK-MB and MDA levels and enhanced SOD activity in $\mathrm{H} / \mathrm{R}+\mathrm{CD} 47$ group $(\mathrm{P}<0.01)$. Compared with the control group, the autophagy inhibitor CQ significantly increased LDH, CK-MB and MDA levels and weakened SOD activity in $\mathrm{H} / \mathrm{R}+\mathrm{CD} 47+\mathrm{CQ}$ group $(\mathrm{P}<0.01)$.

To assess the effects of CD47 deficiency on ROS production, intracellular generation of the ROS moiety $\mathrm{O}_{2}^{-}$was visualized with the fluoroprobe DHE (Fig. 1E). The superoxide anion oxidizes DHE to a novel product that binds to DNA, leading to enhanced fluorescence. In this assay, confocal microscopy demonstrated that cell slides from the H/R group exhibited widespread and significant increases in DHE fluorescence compared with those from the control group $(\mathrm{P}<0.01$; Fig. $1 \mathrm{~F})$ and CD47 antibody treatment in the H/R+CD47 group significantly decreased ROS fluorescence intensity compared with $\mathrm{H} / \mathrm{R}$ alone $(\mathrm{P}<0.01)$. However, the autophagy inhibitor $\mathrm{CQ}$ significantly increased the ROS fluorescence intensity in the $\mathrm{H} / \mathrm{R}+\mathrm{CD} 47+\mathrm{CQ}$ group $(\mathrm{P}<0.01)$.

Annexin V/PI double staining was used to assess the apoptotic rate of the $\mathrm{H} 9 \mathrm{c} 2$ cells (Fig. 1G). There was no significant difference in apoptotic rates between the control and CD47 groups (Fig. 1H). Compared with the control group, 

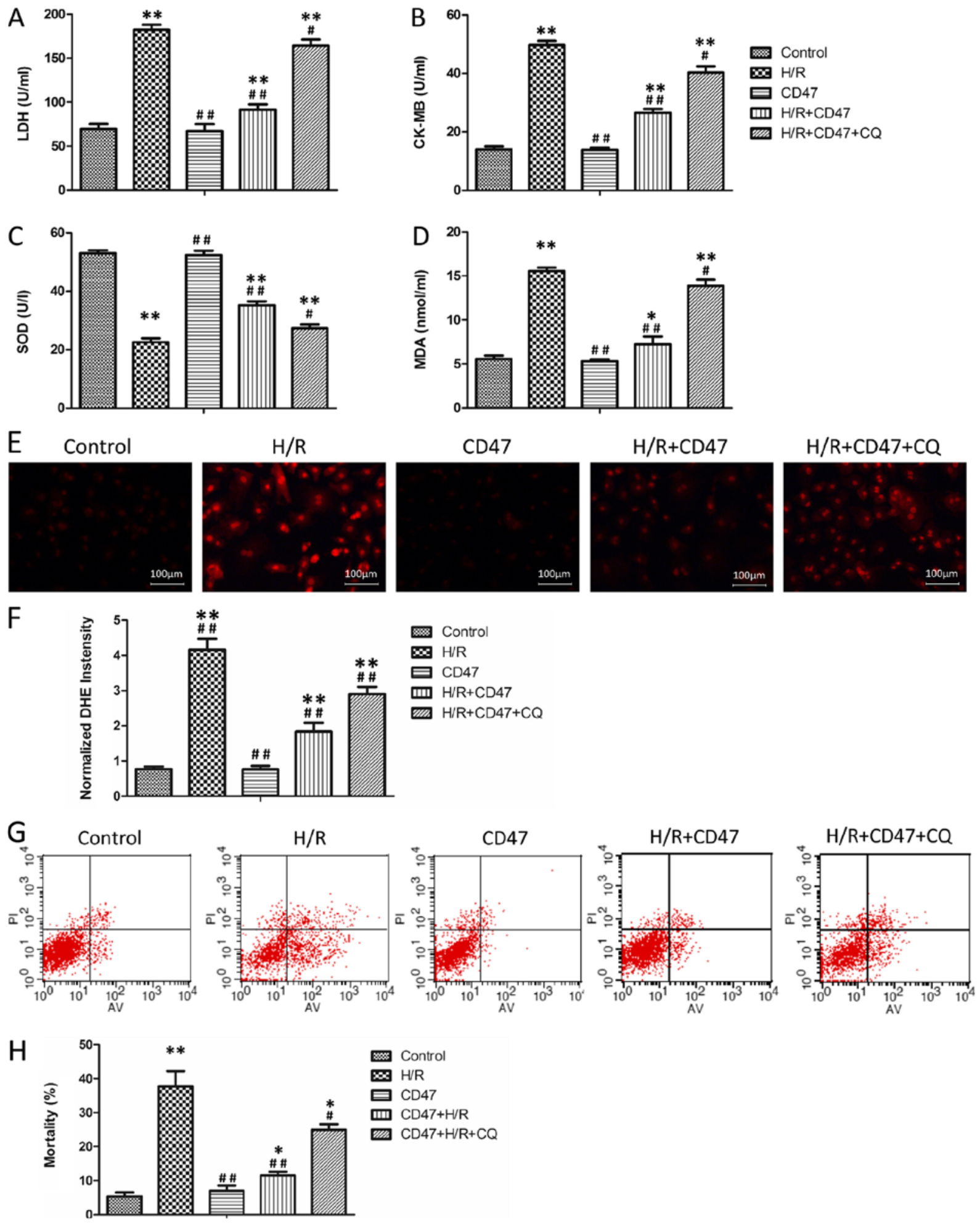

Figure 1. CD47 protects cardiomyocytes against H/R-induced function oxidative stress and apoptosis. The biochemical parameters of the medium supernatant, including (A) LDH, (B) CK-MB and (C) SOD activities and (D) MDA level, were measured (n=9). (E) The ROS levels in the cells from all groups were revealed by DHE staining. (F) The fluorescence intensity of DHE staining was analyzed using Image-Pro Plus (n=9). (G) Quantitative assessment of cell mortality by Annexin V-FITC/PI staining. Intact cells are $\mathrm{V}^{-} / \mathrm{PI}^{-}$, early apoptotic cells are $\mathrm{V}^{+} / \mathrm{PI}^{-}$, late apoptotic cells are $\mathrm{Annexin} \mathrm{V}^{+} / \mathrm{PI}^{+}$and necrotic cells are Annexin $\mathrm{V}^{-} / \mathrm{PI}^{+}$. The figures are representative images of three different experiments. (H) Flow cytometry results are displayed as quantitative bar graphs. Mortality is defined as the percentage of Annexin $\mathrm{V}^{+}$cells $(\mathrm{n}=9)$. The data were collected from three different experiments. Data are presented as the mean \pm standard deviation. Statistical significance: ${ }^{*} \mathrm{P}<0.05$ and ${ }^{* *} \mathrm{P}<0.01$ vs. the control group, ${ }^{\#} \mathrm{P}<0.05$ and ${ }^{\# \#} \mathrm{P}<0.01$ vs. the $\mathrm{H} / \mathrm{R}$ group, respectively. SOD, superoxide dismutase; MDA, malondialdehyde; LDH, lactate dehydrogenase; $\mathrm{CD}$, cluster of differentiation; CK-MB, creatine kinase; PI, propidium iodide; FITC, fluorescein isothiocyanate; $\mathrm{CQ}$, chloroquine; $\mathrm{H} / \mathrm{R}$, hypoxia/reoxygenation.

$H / R$ treatment significantly increased the apoptotic rate in the $\mathrm{H} / \mathrm{R}$ group $(\mathrm{P}<0.01)$. Compared with the $\mathrm{H} / \mathrm{R}$ group, $\mathrm{CD} 47$ antibody treatment significantly decreased the apoptotic rate in the $\mathrm{H} / \mathrm{R}+\mathrm{CD} 47$ group $(\mathrm{P}<0.01)$. Compared with the control 

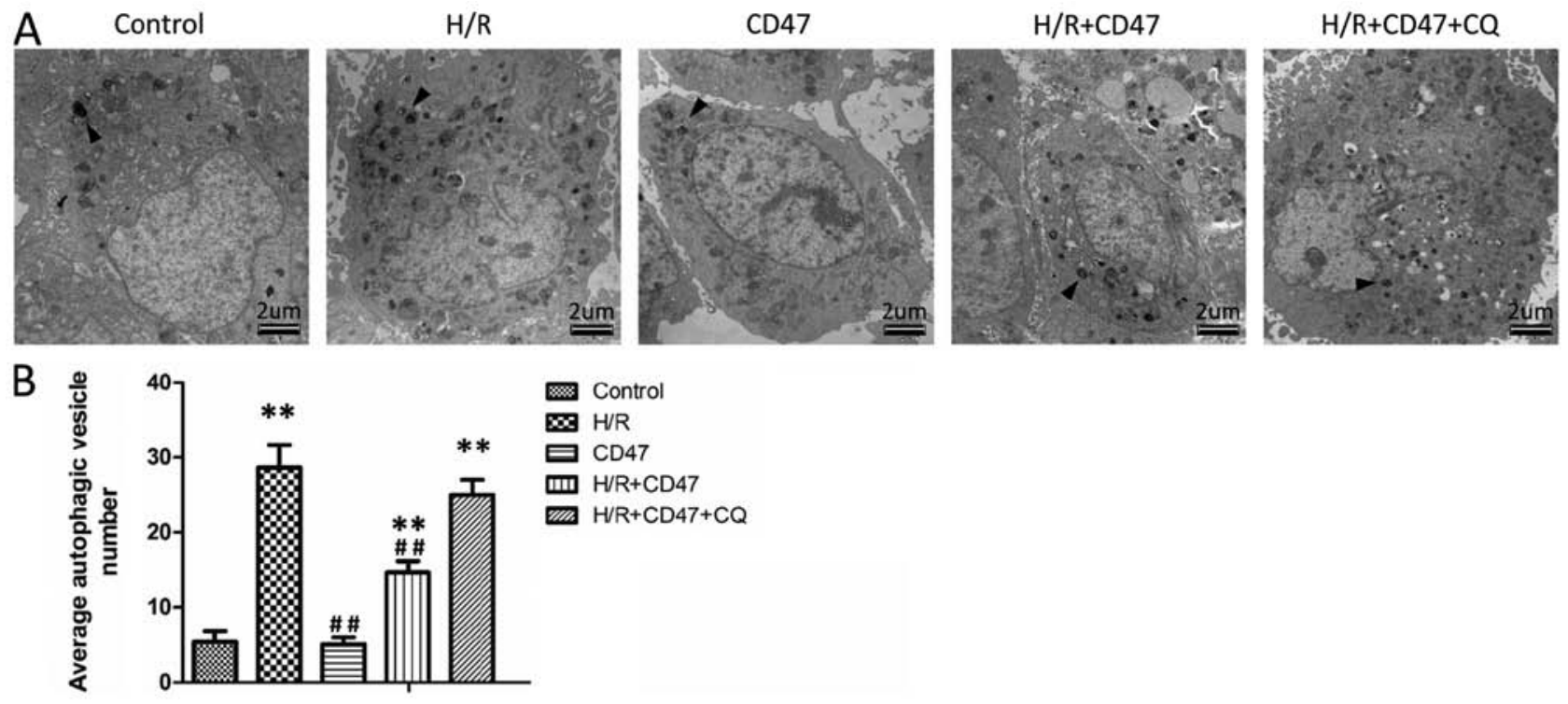

Figure 2. CD47 antibody reduces the accumulation of autophagosome in H/R-treated cardiomyocytes. (A) AV were detected by TEM in H9c2 cells subjected to H/R. AVs (black arrows) by TEM were measured. The figures are representative images of three different experiments. (B) AVs in different groups are quantified and presented as bar graphs $(\mathrm{n}=9)$. Data are presented as the mean \pm standard deviation. Statistical significance: ${ }^{* *} \mathrm{P}<0.01$ vs. the control group, ${ }^{\# \#} \mathrm{P}<0.01$ vs. the H/R group, respectively. AVs, autophagic vesicles; TEMs transmission electron microscope; H/R, hypoxia/reoxygenation; CQ, chloroquine; $\mathrm{CD}$, cluster of differentiation.

group, the autophagy inhibitor CQ significantly increased the apoptotic rate in the $\mathrm{H} / \mathrm{R}+\mathrm{CD} 47+\mathrm{CQ}$ group $(\mathrm{P}<0.05)$.

CD47 suppresses the accumulation of autophagosomes in $H / R$-treated cardiomyocytes. TEM results demonstrated that there was no significant difference in apoptotic rates between the control and CD47 groups (Fig. 2A and B). Compared with the control group, H/R treatment significantly increased autophagic vesicle number in the $H / R$ group $(\mathrm{P}<0.01)$. Compared with the H/R group, CD47 treatment significantly decreased the autophagic vesicle number in the H/R+CD47 group $(\mathrm{P}<0.01)$. Compared with the control group, the autophagy inhibitor CQ significantly increased the autophagic vesicle number in the $\mathrm{H} / \mathrm{R}+\mathrm{CD} 47+\mathrm{CQ}$ group $(\mathrm{P}<0.01)$.

CD47 inhibits the accumulation of protein aggregates in H/R-treated cardiomyocytes. As presented in Fig. 3, there was no significant difference in Beclin-1 and Vimentin expression between the control and CD47 groups. Compared with the control group, CD47 treatment significantly decreased CD47 fluorescence intensity in the CD47 group $(\mathrm{P}<0.01)$. Compared with the control group, $\mathrm{H} / \mathrm{R}$ treatment significantly increased CD47, Beclin-1 and Vimentin expression in the H/R group $(\mathrm{P}<0.01)$. Compared with the $\mathrm{H} / \mathrm{R}$ group, CD47 antibody treatment in the $\mathrm{H} / \mathrm{R}+\mathrm{CD} 47$ group significantly decreased CD47, Beclin-1 and Vimentin expression $(\mathrm{P}<0.05$ and $\mathrm{P}<0.01$, respectively). Compared with the control group, the autophagy inhibitor CQ significantly increased Beclin-1 and Vimentin expression in the $\mathrm{H} / \mathrm{R}+\mathrm{CD} 47+\mathrm{CQ}$ group $(\mathrm{P}<0.01)$.

CD47 protects cardiomyocytes against H/R injury through rescuing impaired autophagy flux. As presented in Fig. 4, the expression levels of LC3-II, Beclin-1, p62, LAMP2, Cleaved caspase- 3 and cleaved caspase- 9 exhibited no significant difference between the control and CD47 groups. Compared with the control group, H/R treatment significantly increased LC3-II, Beclin-1, p62, cleaved caspase-3 and cleaved caspase-9 protein levels and significantly decreased LAMP2 protein level in the $H / R$ group $(\mathrm{P}<0.01)$. Compared with the H/R group, CD47 treatment significantly decreased LC3-II, Beclin-1, p62 protein, cleaved caspase-3 and cleaved caspase- 9 levels and significantly increased LAMP2 protein level in the $\mathrm{H} / \mathrm{R}+\mathrm{CD} 47$ group $(\mathrm{P}<0.01)$. However, compared with the control group, the autophagy inhibitor CQ significantly increased LC3-II, Beclin-1, p62 protein, cleaved caspase-3 and cleaved caspase-9 levels and decreased LAMP2 protein level in the $\mathrm{H} / \mathrm{R}+\mathrm{CD} 47+\mathrm{CQ}$ group $(\mathrm{P}<0.01$ and $\mathrm{P}<0.05$, respectively).

Downregulating CD47 expression inhibits H/R-induced oxidative stress and apoptosis in cardiomyocytes. To investigate the action of CD47 in H9C2 cells, CD47 expression was knocked-down using RNA interference technology (Si-CD47), along with a non-targeting $\mathrm{Si}-\mathrm{NC}$ that was constructed to use as a negative control in all assays. The interference efficiency of Si-CD47 on H9c2 expression is demonstrated in Fig. 5A. Compared with the $\mathrm{Si}-\mathrm{NC}, \mathrm{Si}-\mathrm{CD} 47$ exerted significantly increased efficiency in knocking down CD47 mRNA expression $(\mathrm{P}<0.01$; an inhibition rate of $62 \%)$. Western blotting results (Fig. 5B and C) indicated that the protein expression of CD47 in the Si-CD47 group was decreased compared with in the $\mathrm{Si}-\mathrm{NC}$ group $(\mathrm{P}<0.01)$.

The effects of si-CD47 on cardiomyocytic function and oxidative stress levels in $\mathrm{H} 9 \mathrm{c} 2$ are presented in Fig. 6A-D. Compared with the Si-CD47 group, H/R treatment significantly increased LDH, CK-MB and MDA levels and significantly decreased SOD activity in $\mathrm{H} 9 \mathrm{C} 2$ cells in the $\mathrm{Si}-\mathrm{NC}+\mathrm{H} / \mathrm{R}$ group $(\mathrm{P}<0.01)$. Compared with the $\mathrm{Si}-\mathrm{NC}+\mathrm{H} / \mathrm{R}$ group, $\mathrm{CD} 47$ downregulation decreased LDH, CK-MB and MDA levels and increased SOD activity in the Si-CD47+H/R group $(\mathrm{P}<0.01)$. 
A

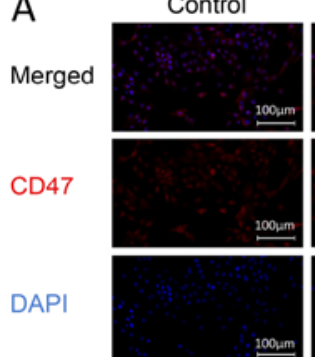

Merged

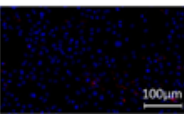

Beclin-1

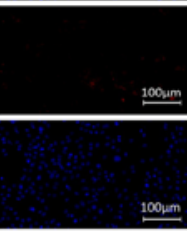

DAPI

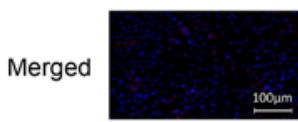

Vimenti

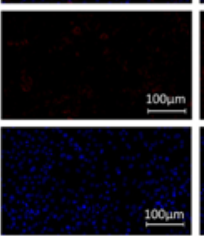

H/R
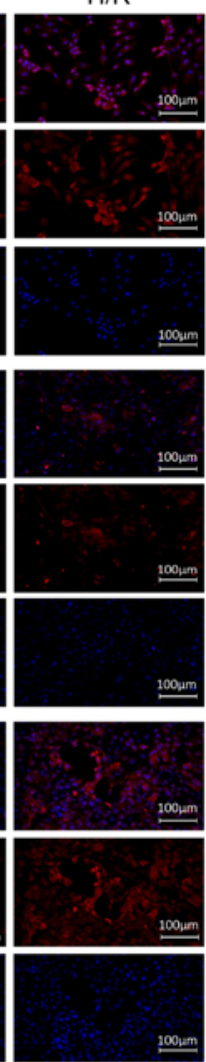
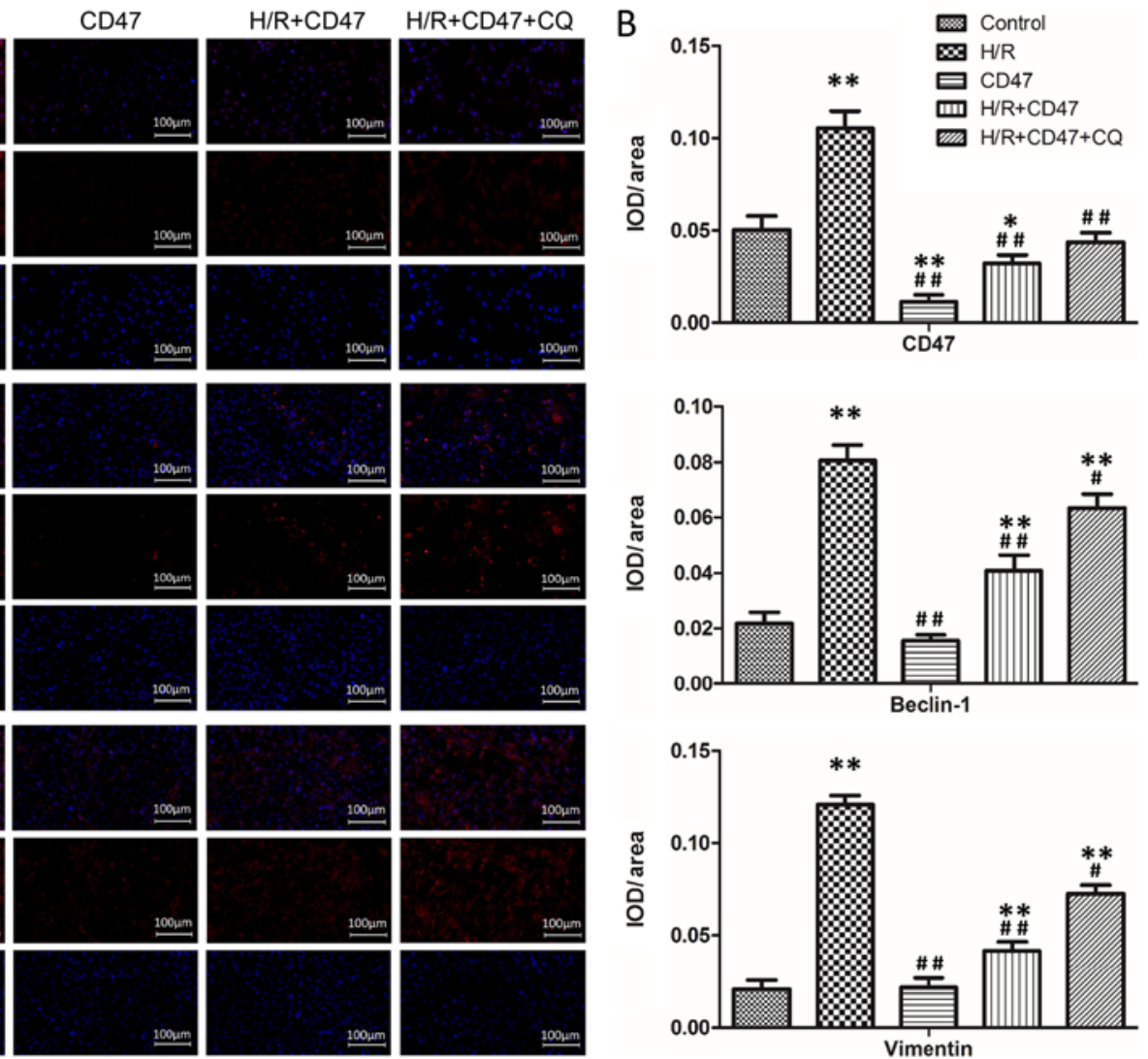

Figure 3. CD47 inhibits the accumulation of protein aggregates in H/R-induced cardiomyocytes. (A) Representative immunofluorescent staining images for CD47, Beclin-1 and Vimentin in H9c2 cells subjected to H/R. The figures are representative images of three different experiments. (B) Semi-quantitative evaluation of CD47, Beclin-1 and Vimentin expression are represented as IOD/Area ( $\mathrm{n}=9)$. Area, $\mu \mathrm{m}^{2}$. Data are presented as the mean \pm standard deviation. Statistical significance: ${ }^{*} \mathrm{P}<0.05$ and ${ }^{* *} \mathrm{P}<0.01$ vs. the control group, ${ }^{\#} \mathrm{P}<0.05$ and ${ }^{\# \#} \mathrm{P}<0.01$ vs. the H/R group, respectively. CD, cluster of differentiation; $\mathrm{H} / \mathrm{R}$, hypoxia/reoxygenation; IOD, integrated optical density; CQ, chloroquine.

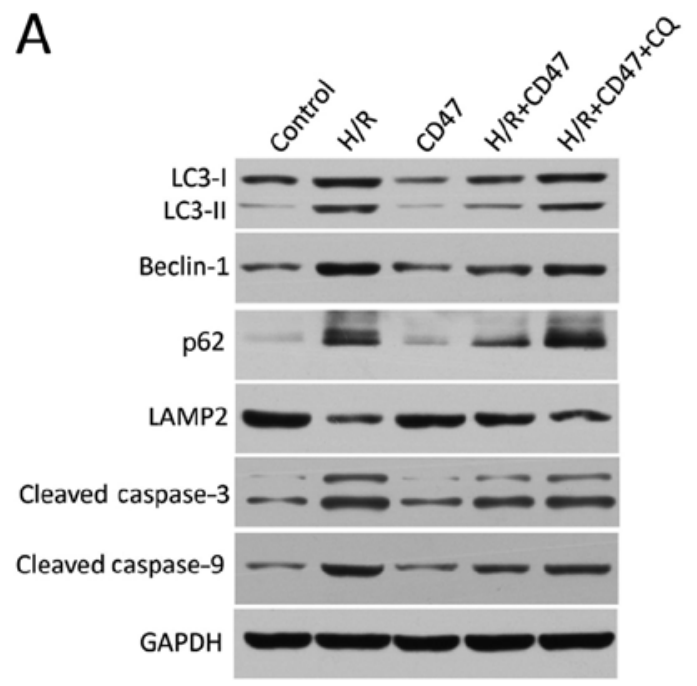

\section{B}

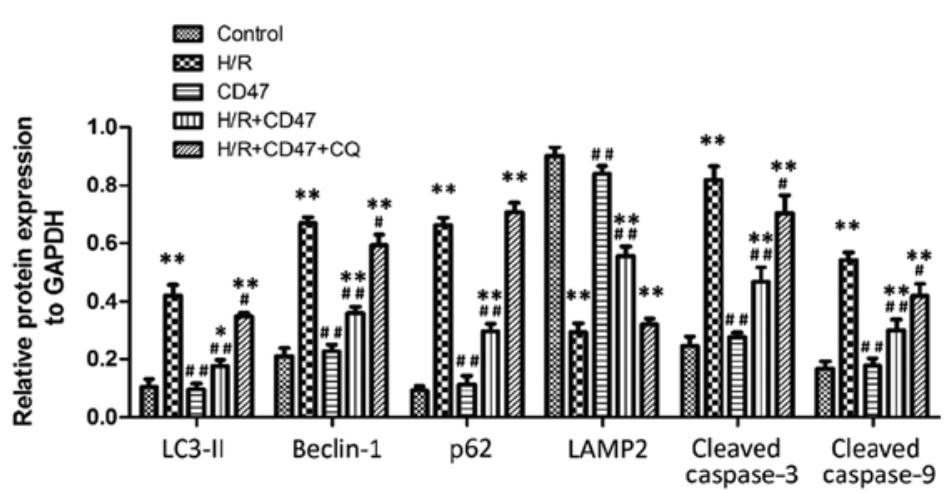

Figure 4. CD47 antibody protects cardiomyocytes against H/R injury through rescuing impaired autophagy flux. (A) Representative western blotting images depicting the protein levels of LC3-II, Beclin-1, p62, LAMP2, cleaved caspase-3 and cleaved caspase-9 in H9C2. The figures are representative images of three different experiments. (B) The protein expression levels are quantitatively analyzed $(n=6)$. Data are presented as the mean \pm standard deviation. Statistical significance: ${ }^{*} \mathrm{P}<0.05$ and ${ }^{* *} \mathrm{P}<0.01$ vs. the control group, ${ }^{\#} \mathrm{P}<0.05$ and ${ }^{\# \#} \mathrm{P}<0.01$ vs. the $\mathrm{H} / \mathrm{R}$ group, respectively. H/R, hypoxia/reoxygenation; $\mathrm{CD}$, cluster of differentiation; $\mathrm{CQ}$, chloroquine.

Annexin V/PI double staining was used to assess the apoptotic rate in the H9c2 cells (Fig. 6E). Compared with the Si-CD47 group, $\mathrm{H} / \mathrm{R}$ treatment significantly increased the apoptotic rate in the $\mathrm{Si}-\mathrm{NC}+\mathrm{H} / \mathrm{R}$ group $(\mathrm{P}<0.01 ;$ Fig. $6 \mathrm{~F})$. Compared with the $\mathrm{H} / \mathrm{R}$ group, $\mathrm{CD} 47$ downregulation significantly decreased the apoptotic rate in the $\mathrm{Si}-\mathrm{CD} 47+\mathrm{H} / \mathrm{R}$ group $(\mathrm{P}<0.01)$. 


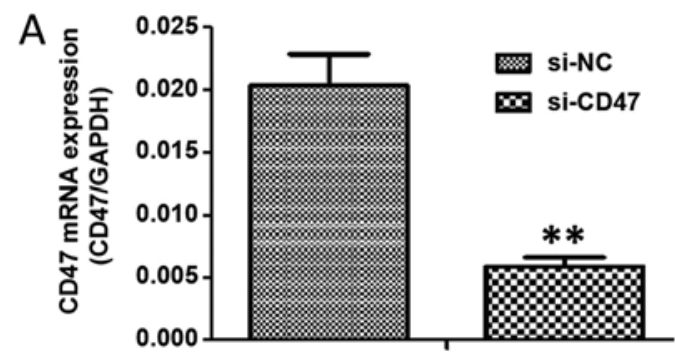

B

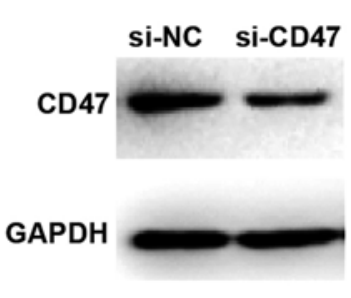

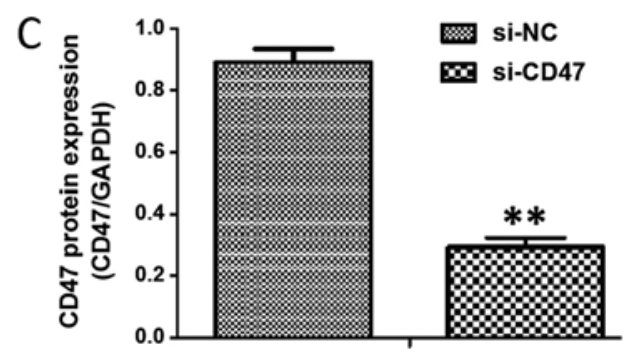

Figure 5. CD47 downregulation significantly reduces CD47 expression in H9c2 cells. (A) Quantitative polymerase chain reaction analysis demonstrated that CD47 mRNA level of H9c2 cells transfected with Si-CD47 was significantly reduced compared with that with Si-NC. (B) Western blot analysis and (C) densitometric analysis demonstrated that CD47 protein level of H9c2 cells transfected with Si-CD47 was significantly reduced compared with that with Si-NC. Data are presented as the mean \pm standard deviation. Statistical significance: ${ }^{* *} \mathrm{P}<0.01$ vs. the Si-NC group. Si-NC, small interfering-negative control; $\mathrm{CD}$, cluster of differentiation.
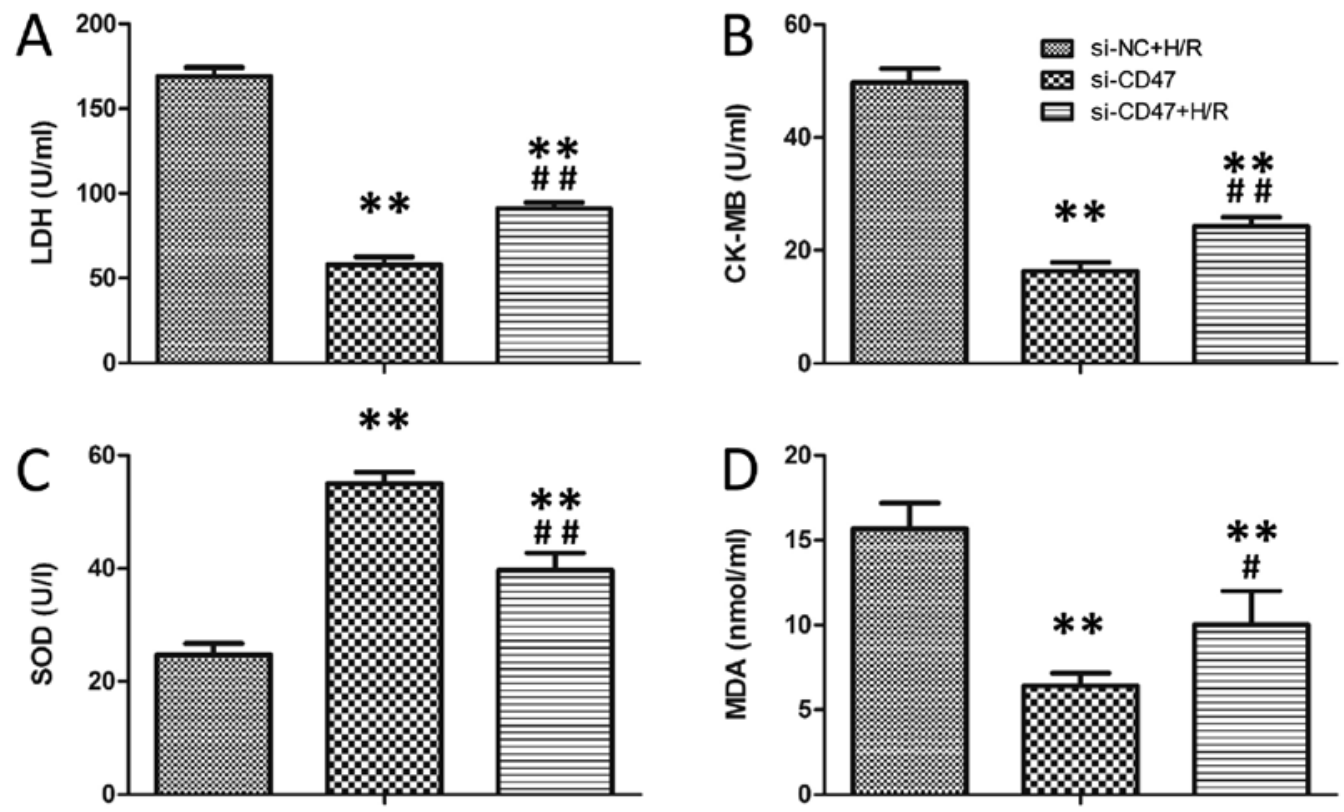

$\mathrm{E}$
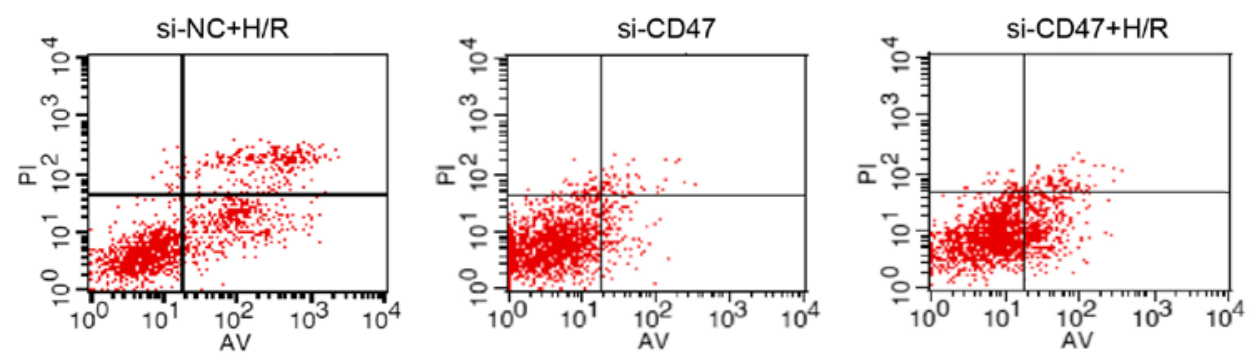

$\mathrm{F}$

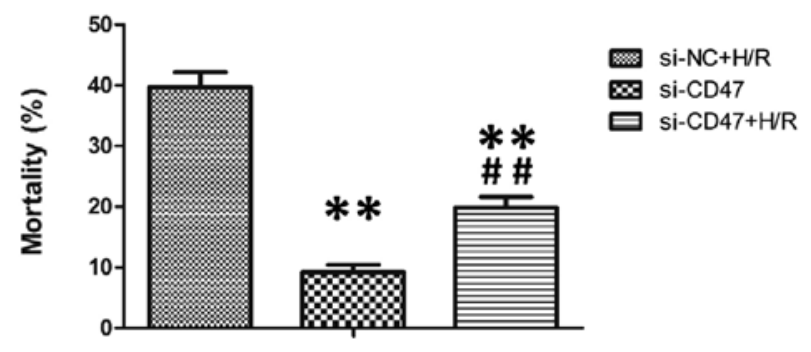

Figure 6. CD47 downregulation protects cardiomyocytes against H/R-induced oxidative stress. The biochemical parameters of the medium supernatant, including (A) LDH, (B) CK-MB and (C) SOD activities and (D) MDA level, were measured (n=6). (E) Quantitative assessment of mortality by Annexin V-FITC/PI staining. Intact cells are $\mathrm{V}^{-} / \mathrm{PI}^{-}$, early apoptotic cells are $\mathrm{V}^{+} / \mathrm{PI}^{\prime}$, late apoptotic cells are Annexin $\mathrm{V}^{+} / \mathrm{PI}^{+}$and necrotic cells are Annexin $\mathrm{V}^{-} / \mathrm{PI}^{+}$. The figures are representative images of three different experiments. (F) Flow cytometry results are displayed as quantitative bar graphs. Cell mortality is defined as the percentage of Annexin $\mathrm{V}^{+}$cells $(\mathrm{n}=6)$. The data were collected from three different experiments. All data are presented as the mean \pm standard deviation. Statistical significance: ${ }^{* *} \mathrm{P}<0.01$ vs. the Si-NC group, ${ }^{\#} \mathrm{P}<0.05$ and ${ }^{\# \#} \mathrm{P}<0.01$ vs. the Si-CD47+H/R group, respectively. SOD, superoxide dismutase; $\mathrm{PI}$, propidium iodide; FITC, fluorescein isothiocyanate; LDH, lactate dehydrogenase; MDA, malondialdehyde; H/R, hypoxia/reoxygenation; CK-MB, creatinine kinase-MB; CD, cluster of differentiation. 
A

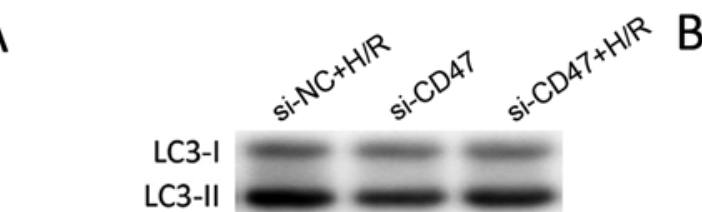

B
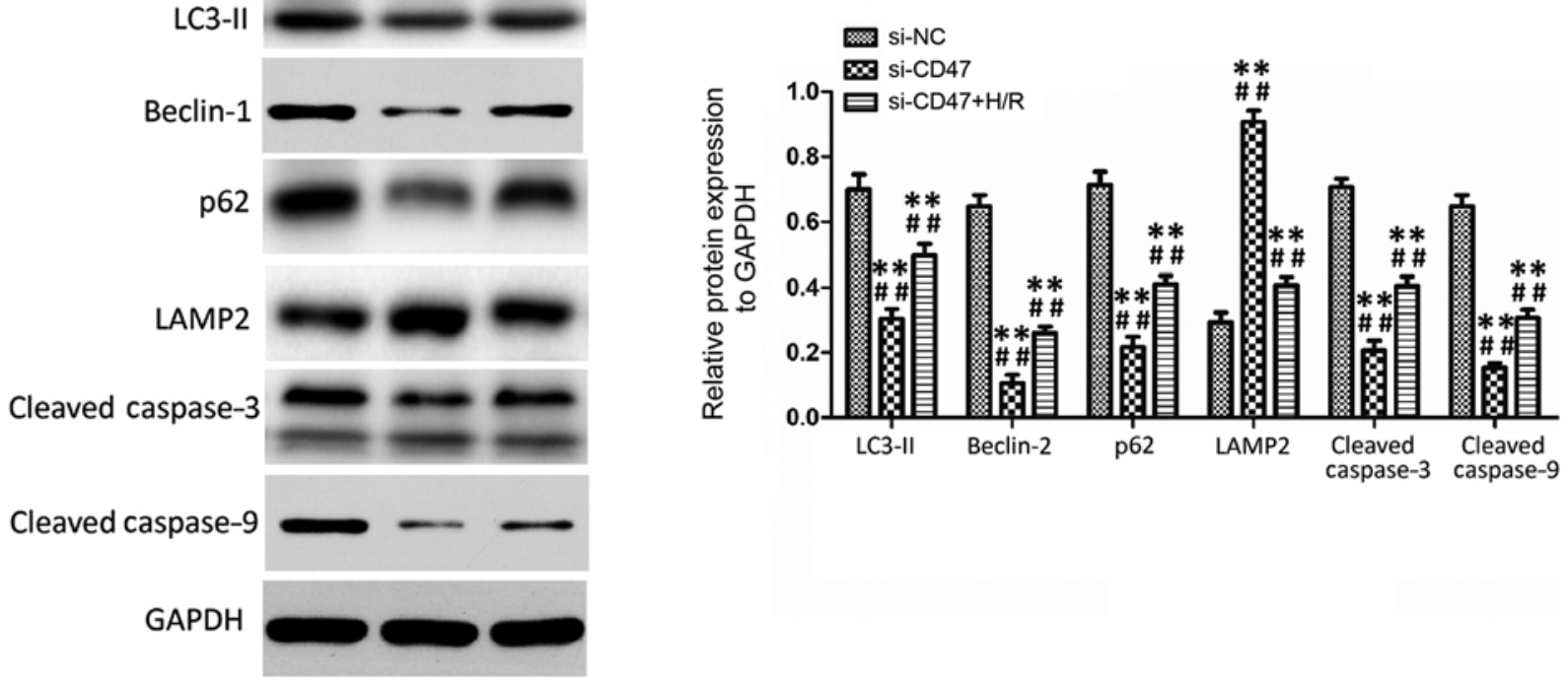

Figure 7. CD47 downregulation protects cardiomyocytes against H/R injury through rescuing impaired autophagic flux. (A) Representative western blots images depicting protein levels of LC3-II, Beclin-1, p62, LAMP2, cleaved caspase-3 and cleaved caspase-9 in H9c2 cells. The figures are representative images of three different experiments. (B) The protein expression levels are quantitatively analyzed $(n=6)$. Data are presented as the mean \pm standard deviation. Statistical significance: ${ }^{* *} \mathrm{P}<0.01$ vs. the Si-NC group, ${ }^{\# \#} \mathrm{P}<0.01$ vs. the Si-CD47+H/R group, respectively. Si-NC, small interfering; $\mathrm{CD}$, cluster of differentiation; $\mathrm{H} / \mathrm{R}$, hypoxia/reoxygenation.

CD47 protects cardiomyocytes against H/R injury through rescuing impaired autophagy flux. As presented in Fig. 7, H/R treatment significantly increased LC3-II, Beclin-1, p62, cleaved caspase-3 and cleaved caspase-9 protein levels and significantly decreased LAMP2 protein level in the $\mathrm{Si}-\mathrm{NC}+\mathrm{H} / \mathrm{R}$ group compared with the $\mathrm{Si}-\mathrm{CD} 47$ group $(\mathrm{P}<0.01)$. Compared with the $\mathrm{Si}-\mathrm{NC}+\mathrm{H} / \mathrm{R}$ group, $\mathrm{CD} 47$ downregulation group significantly decreased LC3-II, Beclin-1, p62 protein, cleaved caspase- 3 and cleaved caspase- 9 levels and significantly increased LAMP2 protein level in Si-CD47+H/R $(\mathrm{P}<0.01)$.

\section{Discussion}

CD47 deficiency has been reported to protect normal cells and tissues from I/R injury-induced apoptosis $(11,12,28-40)$. However, the molecular mechanism behind this protection remains obscure. In the present study, CD47 downregulation protected cardiomyocytes against H/R injury in H9c2 cells, an effect largely attributed to the inhibition of autophagy. It was demonstrated that more obvious cardiomyocyte function damage, oxidative stress, protein aggregation, cardiomyocyte apoptosis and autophagy inhibition appeared in untreated $\mathrm{H} / \mathrm{R} \mathrm{H9c2}$ cells, and that all these changes were decreased by CD47 downregulation through autophagy promotion; moreover, the autophagosome-lysosome fusion inhibitor CQ reversed the effect of CD47 treatment.

Oxidative stress and apoptosis are two major mechanisms involved in cardiomyocyte injury following hypoxia and I/R (31-33). Autophagy regulates intracellular homeostasis and cardiomyocytic survival. Mounting evidence supports the idea that ROS and autophagosome accumulation induce autophagy (34-36). Autophagosome accumulation hampers the clearance of damaged intracellular organelles and proteins, resulting in overproduction of ROS (37). Oxidative stress serves a central role in myocardial I/R injury $(38,39)$. During injury, the blood supply is re-established in the ischemic myocardium and superabundant oxygen free radicals are generated to trigger oxidative stress and aggravate myocardium I/R injury (40). Through autophagy protein aggregates and damaged organelles are removed from the cytoplasm $(3,41)$. Once autophagy is disrupted, the resultant autophagosome accumulation increases ROS production and mitochondrial permeability, a process ending in cell death (6). As demonstrated in the present study, this process can be attenuated by CD47 antibody or Si-CD47 pretreatment. The results of the present study indicate that CD47 downregulation can inhibit apoptosis by the oxidative stress pathway.

$\mathrm{I} / \mathrm{R}$ injury in $\mathrm{H} 9 \mathrm{c} 2$ cells is a complex biochemical cascade that is initiated after ischemia and is exacerbated after the return of blood flow. I/R causes both cardiomyocytic death and autophagy in H9c2 cells (41). Autophagy has a dual role in cell development during heart ischemia and reperfusion (42). Autophagy maintains the homeostasis of cellular ATP and ensures cell survival in the ischemic heart (43). However, excessive autophagy can cause cell death during reperfusion (44). In the present study, both $\mathrm{H} / \mathrm{R}$-induced apoptosis and autophagy in H9c2 cells were attenuated by CD47 downregulation through increasing autophagosome procession. However, the lysosomal acidification inhibitor CQ prevents autophagosome-lysosome fusion (44) and can neutralize the effect of CD47 antibody treatment. 
Autophagy is regulated by several proteins, including LC3-II, Beclin-1, p62 and LAMP2 (45-48). Therefore, the present study examined the levels of these autophagy-associated proteins in myocytes during $\mathrm{H} / \mathrm{R}$. In mammalian cells, LC3-II becomes membrane-bounding and easy to localize on autophagosomes (49), which in turn makes LC3-II an ideal autophagosomal marker (50). In the present study, the increase of LC3-II expression was associated with reduced cardiomyocytic viability during $\mathrm{H} / \mathrm{R}$, suggesting that autophagy during the reperfusion phase may be detrimental for myocytes. Notably, CD47 antibody or Si-CD47 treatment downregulated the expression of LC3-II and increased the survival rate of $\mathrm{H} 9 \mathrm{c} 2$ cells, indicating that CD47 downregulation can promote cell survival through inhibiting the excessive autophagy induced by H/R.

To further explore the role of CD47 in autophagic flux, the expression of p62 and Beclin-1, which link ubiquitinated aggregates for destruction within autophagosomes, get degraded upon autophagosome processing and increased in I/R-treated hearts, were assessed $(49,51)$. The p62 protein was degraded, indicating that CD47 signaling normally limits cell survival by preventing autophagic flux. Otherwise, Beclin-1, an early-autophagy-related gene (45), activates autophagy during reperfusion and promotes cardiomyocytic apoptosis (3). Downregulating Beclin-1 expression in myocytes can inhibit I/R-induced autophagy and increase cell survival rate (52). Bcl-2 can bind to Beclin-1 to form a Bcl-2-Beclin-1 complex that prevents Beclin-1 from assembling the pre-autophagosomal structure, a process that inhibits autophagy and apoptosis $(53,54)$. Bcl-2 is a potent anti-apoptotic protein (55) and inducing its partner Beclin-1 by loss of CD47 may be a master regulator of the fate decision between apoptotic cell death and protective autophagy. The present study identified Beclin-1 as another target of CD47 signaling pathway.

Another finding of this study was the rapid decline in LAMP2 abundance in the H/R group and the improvement of autophagosome processing by upregulating LAMP2 in the CD47 treatment groups. However, CQ can disrupt the effect of CD47 by inhibiting autophagosome processing. Both ischemia and reperfusion induce the decline of LAMP2, a lysosome membrane protein that participates in autophagosome-lysosome fusion $(47,48)$. This decline can be accelerated by ROS generation (49). LAMP2 knockdown impairs autophagy in ventricular myocytes of adult rats and causes cell apoptosis at a level comparable to that achieved by 3-Methyladenine, another autophagy inhibitor (56). Ablation of LAMP2 (57) or loss of the LAMP2 (58) protein in Danon disease (59), which is characterized by autophagosome accumulation in myocardium and cardiomyopathy (58), can cause extensive myocardial fibrosis (60), suggesting that autophagosome accumulation induced by inhibition of autophagic flux is a pathogenic mechanism responsible for $\mathrm{H} / \mathrm{R}$ injury in cardiomyocytes.

In conclusion, the CD47 antibody or $\mathrm{Si}-\mathrm{CD} 47$ can protect cardiomyocytes against $\mathrm{H} / \mathrm{R}$ injury through increasing autophagic flux and autophagic clearance. CD47 deficiency may offer a potential therapeutic approach for preventing myocardial I/R injury, which should be tested with in vivo experiments.

\section{Acknowledgements}

The authors would like to thank Dr Wei Sun and Dr Peng Li (Department of Cardiology, The First Affiliated Hospital of Nanjing Medical University) for their technical assistance.

\section{Funding}

The present study was supported by the Natural Science Foundation of China (grant no. 81627802).

\section{Availability of data and materials}

The datasets used and/or analyzed during the current study are available from the corresponding author on reasonable request.

\section{Authors' contributions}

DH designed the study and drafted the manuscript. YL and $\mathrm{KZ}$ undertook cell culture and characterization. PZ, HF and YZ helped perform the experiments regarding molecular biological technique. DB and QC helped to perform TEM and immunofluorescence staining. YY, LL and YD assisted with the biochemical index detection. XK provided constructive suggestions on experimental design, performed the data analysis and revised the manuscript. All authors reviewed the manuscript. All authors read and approved the final manuscript.

\section{Ethics approval and consent to participate}

All experiments with animals were approved by the Institutional Animal Care and Use Committee (IACUC) of the Nanjing Medical University and the methods were carried out in accordance with the approved guidelines.

\section{Patient consent for publication}

Not applicable.

\section{Competing interests}

The authors declare that they have no competing interests.

\section{References}

1. Keeley EC, Boura JA and Grines CL: Primary angioplasty versus intravenous thrombolytic therapy for acute myocardial infarction: A quantitative review of 23 randomised trials. Lancet 361: 13-21, 2003.

2. Yellon DM and Hausenloy DJ: Myocardial reperfusion injury. N Engl J Med 357: 1121-1135, 2007.

3. Przyklenk K, Dong Y, Undyala VV and Whittaker P: Autophagy as a therapeutic target for ischaemia/reperfusion injury? Concepts, controversies, and challenges. Cardiovasc Res 94: 197-205, 2012.

4. Jennings RB: Historical perspective on the pathology of myocardial ischemia/reperfusion injury. Circ Res 113: 428-438, 2013.

5. Verma S, Fedak PW, Weisel RD, Butany J, Rao V, Maitland A, Li RK, Dhillon B and Yau TM: Fundamentals of reperfusion injury for the clinical cardiologist. Circulation 105: 2332-2336, 2002.

6. Zhang Y and Ren J: Targeting autophagy for the therapeutic application of histone deacetylase inhibitors in ischemia/reperfusion heart injury. Circulation 129: 1088-1091, 2014. 
7. Ong SB and Gustafsson AB: New roles for mitochondria in cell death in the reperfused myocardium. Cardiovasc Res 94: 190-196, 2012.

8. Zeng M, Wei X, Wu Z, Li W, Li B, Zhen Y, Chen J, Wang P and Fei Y: NF- $\kappa \mathrm{B}-$ mediated induction of autophagy in cardiac ischemia/reperfusion injury. Biochem Biophys Res Commun 436: $180-185,2013$.

9. Wagner C, Tillack D, Simonis G, Strasser RH and Weinbrenner C: Ischemic post-conditioning reduces infarct size of the in vivo rat heart: Role of PI3-K, mTOR, GSK-3beta, and apoptosis. Mol Cell Biochem 339: 135-147, 2010.

10. Ma X, Liu H, Foyil SR, Godar RJ, Weinheimer CJ and Diwan A Autophagy is impaired in cardiac ischemia-reperfusion injury. Autophagy 8: 1394-1396, 2012.

11. Isenberg JS, Maxhimer JB, Powers P, Tsokos M, Frazier WA and Roberts DD: Treatment of liver ischemia/reperfusion injury by limiting thrombospondin-1/CD47 signaling. Surgery 144 : $752-761,2008$

12. Maxhimer JB, Shih HB, Isenberg JS, Miller TW and Roberts DD: Thrombospondin-1/CD47 blockade following ischemia-reperfusion injury is tissue protective. Plast Reconstr Surg 124: 1880-1889, 2009.

13. Sharifi-Sanjani M, Shoushtari AH, Quiroz M, Baust J, Sestito SF, Mosher M, Ross M, McTiernan CF, St Croix CM, Bilonick RA, et al: Cardiac CD47 drives left ventricular heart failure through $\mathrm{Ca}^{2+}-\mathrm{CaMKII}$-regulated induction of HDAC3. J Am Heart Assoc 3: e000670, 2014

14. Sezaki S, Hirohata S, Iwabu A, Nakamura K, Toeda K, Miyoshi T, Yamawaki H, Demircan K, Kusachi S, Shiratori Y and Ninomiya Y: Thrombospondin-1 is induced in rat myocardial infarction and its induction is accelerated by ischemia/reperfusion. Exp Biol Med 230: 621-630, 2005

15. Rogers NM, Thomson AW and Isenberg JS: Activation of parenchymal CD47 promotes renal ischemia-reperfusion injury. J Am Soc Nephrol 23: 1538-1550, 2012.

16. Xiao ZY, Banan B, Jia J, Manning PT, Hiebsch RR, Gunasekaran M, Upadhya GA, Frazier WA, Mohanakumar T, Lin Y and Chapman WC: CD47 blockade reduces ischemia/reperfusion injury and improves survival in a rat liver transplantation model. Liver Transpl 21: 468-477, 2015

17. Lin Y, Manning PT, Jia J, Gaut JP, Xiao Z, Capoccia BJ, Chen CC, Hiebsch RR, Upadhya G, Mohanakumar T, et al: CD47 blockade reduces ischemia-reperfusion injury and improves outcomes in a rat kidney transplant model. Transplantation 98 : 394-401, 2014.

18. Isenberg JS, Pappan LK, Romeo MJ, Abu-Asab M, Tsokos M, Wink DA, Frazier WA and Roberts DD: Blockade of thrombospondin-1-CD47 interactions prevents necrosis of full thickness skin grafts. Ann Surg 247: 180-190, 2008.

19. Rogers NM, Zhang ZJ, Wang JJ, Thomson AW and Isenberg JS CD47 regulates renal tubular epithelial cell self-renewal and proliferation following renal ischemia reperfusion. Kidney Int 90: 334-347, 2016.

20. Maxhimer JB, Soto-Pantoja DR, Ridnour LA, Shih HB, Degraff WG, Tsokos M, Wink DA, Isenberg JS and Roberts DD: Radioprotection in normal tissue and delayed tumor growth by blockade of CD47 signaling. Sci Transl Med 1: 3ra7, 2009.

21. Isenberg JS, Maxhimer JB, Hyodo F, Pendrak ML, Ridnour LA, DeGraff WG, Tsokos M, Wink DA and Roberts DD Thrombospondin-1 and CD47 limit cell and tissue survival of radiation injury. Am J Pathol 173: 1100-1112, 2008.

22. Soto-Pantoja DR, Miller TW, Pendrak ML, DeGraff WG, Sullivan C, Ridnour LA, Abu-Asab M, Wink DA, Tsokos M and Roberts DD: CD47 deficiency confers cell and tissue radioprotection by activation of autophagy. Autophagy 8: 1628-1642, 2012.

23. Cao X, Chen A, Yang P, Song X, Liu Y, Li Z, Wang X, Wang L and Li Y: Alpha-lipoic acid protects cardiomyocytes against hypoxia/reoxygenation injury by inhibiting autophagy. Biochem Biophys Res Commun 441: 935-940, 2013.

24. Zhang B, Zhou M, Li C, Zhou J, Li H, Zhu D, Wang Z, Chen A and Zhao Q: MicroRNA-92a inhibition attenuates Hypoxia/Reoxygenation-induced myocardiocyte apoptosis by targeting Smad7. PLoS One 9: e100298, 2014.

25. Wang Y, Yin $\mathrm{C}$, Feng L, Wang $\mathrm{C}$ and Sheng G: Ara-C and anti-CD47 antibody combination therapy eliminates acute monocytic leukemia THP-1 cells in vivo and in vitro. Genet Mol Res 14: 5630-5641, 2015.

26. Ma X, Godar RJ, Liu H and Diwan A: Enhancing lysosome biogenesis attenuates BNIP3-induced cardiomyocyte death. Autophagy 8: 297-309, 2012.
27. Livak KJ and Schmittgen TD: Analysis of relative gene expression data using real-time quantitative PCR and the 2(-Delta Delta C(T)) method. Methods 25: 402-408, 2001.

28. Wang HB, Yang J, Ding JW, Chen LH, Li S, Liu XW, Yang CJ, Fan ZX and Yang J: RNAi-mediated down-regulation of CD47 protects against ischemia/reperfusion-induced myocardial damage via activation of eNOS in a rat model. Cell Physiol Biochem 40: 1163-1174, 2016.

29. Isenberg JS, Hyodo F, Pappan LK, Abu-Asab M, Tsokos M, Krishna MC, Frazier WA and Roberts DD: Blocking thrombospondin-1/CD47 signaling alleviates deleterious effects of aging on tissue responses to ischemia. Arterioscler Thromb Vasc Biol 27: 2582-2588, 2007.

30. Thakar CV, Zahedi K, Revelo MP, Wang Z, Burnham CE, Barone S, Bevans S, Lentsch AB, Rabb $\mathrm{H}$ and Soleimani M: Identification of thrombospondin 1 (TSP-1) as a novel mediator of cell injury in kidney ischemia. J Clin Invest 115: 3451-3459, 2005.

31. Chen HW, Chien CT, Yu SL, Lee YT and Chen WJ: Cyclosporine A regulate oxidative stress-induced apoptosis in cardiomyocytes: Mechanisms via ROS generation, iNOS and Hsp70. Br J Pharmacol 137: 771-781, 2002.

32. Webster KA, Discher DJ, Kaiser S, Hernandez O, Sato B and Bishopric NH: Hypoxia activated apoptosis of cardiac myocytes requires reoxygenation or a $\mathrm{pH}$ shift and is independent of $\mathrm{p} 53$. J Clin Invest 104: 239-252, 1999.

33. Lee Y and Gustafsson AB: Role of apoptosis in cardiovascular disease. Apoptosis 14: 536-548, 2009.

34. Jaber N, Dou Z, Chen JS, Catanzaro J, Jiang YP, Ballou LM, Selinger E, Ouyang X, Lin RZ, Zhang J and Zong WX: Class III PI3K Vps34 plays an essential role in autophagy and in heart and liver function. Proc Natl Acad Sci USA 109: 2003-2008, 2012.

35. Saiki S, Sasazawa Y, Imamichi Y, Kawajiri S, Fujimaki T, Tanida I, Kobayashi H, Sato F, Sato S, Ishikawa K, et al: Caffeine induces apoptosis by enhancement of autophagy via PI3K/Akt/mTOR/p70S6K inhibition. Autophagy 7: 176-187, 2011.

36. Tannous P, Zhu H, Nemchenko A, Berry JM, Johnstone JL, Shelton JM, Miller FJ Jr, Rothermel BA and Hill JA: Intracellular protein aggregation is a proximal trigger of cardiomyocyte autophagy. Circulation 117: 3070-3078, 2008.

37. Kroemer G, Galluzzi L, Vandenabeele P, Abrams J, Alnemri ES, Baehrecke EH, Blagosklonny MV, El-Deiry WS, Golstein P, Green DR, et al: Classification of cell death: Recommendations of the Nomenclature Committee on Cell Death. Cell Death Differ 16: 3-11, 2009.

38. Kurian GA, Rajagopal R, Vedantham S and Rajesh M: The role of oxidative stress in myocardial ischemia and reperfusion injury and remodeling: Revisited. Oxid Med Cell Longev 2016: $1656450,2016$.

39. Zhang W, Han Y, Meng G, Bai W, Xie L, Lu H, Shao Y, Wei L, Pan S,Zhou S, et al: Direct renin inhibition with aliskiren protects against myocardial ischemia/reperfusion injury by activating nitric oxide synthase signaling in spontaneously hypertensive rats. J Am Heart Assoc 3: e000606, 2014.

40. Chen C, Chen W, Nong Z, Ma Y, Qiu S and Wu G: Cardioprotective effects of combined therapy with hyperbaric oxygen and diltiazem pretreatment on myocardial ischemia-reperfusion injury in rats. Cell Physiol Biochem 38: 2015-2019, 2016.

41. Matsui Y, Takagi H, Qu X, Abdellatif M, Sakoda H, Asano T, Levine B and Sadoshima J: Distinct roles of autophagy in the heart during ischemia and reperfusion: Roles of AMP-activated protein kinase and Beclin-1 in mediating autophagy. Circ Res 100: 914-922, 2007.

42. Takagi H, Matsui Y and Sadoshima J: The role of autophagy in mediating cell survival and death during ischemia and reperfusion in the heart. Antioxid Redox Signal 9: 1373-1381, 2007.

43. Takagi H, Matsui Y, Hirotani S, Sakoda H, Asano T and Sadoshima J: AMPK mediates autophagy during myocardial ischemia in vivo. Autophagy 3: 405-407, 2007.

44. Iwai-Kanai E, Yuan H, Huang C, Sayen MR, Perry-Garza CN, Kim L and Gottlieb RA: A method to measure cardiac autophagic flux in vivo. Autophagy 4: 322-329, 2008.

45. He C and Levine B: The Beclin 1 interactome. Curr Opin Cell Biol 22: 140-149, 2010.

46. Levine B and Ranganathan R: Autophagy: Snapshot of the network. Nature 466: 38-40, 2010

47. Eskelinen EL, Illert AL, Tanaka Y, Schwarzmann G, Blanz J, Von Figura K and Saftig P: Role of LAMP-2 in lysosome biogenesis and autophagy. Mol Biol Cell 13: 3355-3368, 2002. 
48. Huynh KK, Eskelinen EL, Scott CC, Malevanets A, Saftig P and Grinstein S: LAMP proteins are required for fusion of lysosomes with phagosomes. EMBO J 26: 313-324, 2007.

49. Ma X, Liu H, Foyil SR, Godar RJ, Weinheimer CJ, Hill JA and Diwan A: Impaired autophagosome clearance contributes to cardiomyocyte death in ischemia/reperfusion injury. Circulation 125: 3170-3181, 2012.

50. Tanida I, Ueno T and Kominami E: LC3 conjugation system in mammalian autophagy. Int J Biochem Cell Biol 36: 2503-2518, 2004.

51. Paglin S, Hollister T, Delohery T, Hackett N, McMahill M, Sphicas E, Domingo D and Yahalom J: A novel response of cancer cells to radiation involves autophagy and formation of acidic vesicles. Cancer Res 61: 439-444, 2001.

52. Valentim L, Laurence KM, Townsend PA, Carroll CJ, Soond S, Scarabelli TM, Knight RA, Latchman DS and Stephanou A: Urocortin inhibits Beclin1.mediated autophagic cell death in cardiac myocytes exposed to ischaemia/reperfusion injury. $\mathrm{J} \mathrm{Mol}$ Cell Cardiol 40: 846-852, 2006.

53. Liang XH, Kleeman LK, Jiang HH, Gordon G, Goldman JE, Berry G, Herman B and Levine B: Protection against fatal Sindbis virus encephalitis by beclin, a novel Bcl-2-interacting protein. J Virol 72: 8586-8596, 1998.

54. Pattingre S, Tassa A, Qu X, Garuti R, Liang XH, Mizushima N, Packer M, Schneider MD and Levine B: Bcl-2 antiapoptotic proteins inhibit Beclin 1-dependent autophagy. Cell 122: 927-939, 2005.

55. Akar U, Chaves-Reyez A, Barria M, Tari A, Sanguino A, Kondo Y, Kondo S, Arun B, Lopez-Berestein G and Ozpolat B: Silencing of Bcl-2 expression by small interfering RNA induces autophagic cell death in MCF-7 breast cancer cells. Autophagy 4 669-679, 2008.
56. Maruyama R, Goto K, Takemura G, Ono K, Nagao K, Horie T, Tsujimoto A, Kanamori $\mathrm{H}$, Miyata S, Ushikoshi $\mathrm{H}$, et al: Morphological and biochemical characterization of basal and starvation-induced autophagy in isolated adult rat cardiomyocytes. Am J Physiol Heart Circ Physiol 295: H1599-H1607, 2008.

57. Nakai A, Yamaguchi O, Takeda T, Higuchi Y, Hikoso S, Taniike M, Omiya S, Mizote I, Matsumura Y, Asahi M, et al: The role of autophagy in cardiomyocytes in the basal state and in response to hemodynamic stress. Nat Med 13: 619-624, 2007.

58. Tanaka Y, Guhde G, Suter A, Eskelinen EL, Hartmann D, Lüllmann-Rauch R, Janssen PM, Blanz J, von Figura K and Saftig P: Accumulation of autophagic vacuoles and cardiomyopathy in LAMP-2-deficient mice. Nature 406: 902-906, 2000.

59. Nishino I, Fu J, Tanji K, Yamada T, Shimojo S, Koori T, Mora M, Riggs JE, Oh SJ, Koga Y, et al: Primary LAMP-2 deficiency causes X-linked vacuolar cardiomyopathy and myopathy (Danon disease). Nature 406: 906-910, 2000.

60. Maron BJ, Roberts WC, Arad M, Haas TS, Spirito P, Wright GB, Almquist AK, Baffa JM, Saul JP, Ho CY, et al: Clinical outcome and phenotypic expression in LAMP2 cardiomyopathy. JAMA 301: 1253-1259, 2009. 